\title{
PENETAPAN MAHAR TERHADAP KELANGSUNGAN PERNIKAHAN DITINJAU MENURUT HUKUM ISLAM
}

\author{
Putra Halomoan \\ Fakultas Syariah dan Ilmu Hukum IAIN Padangsidimpuan \\ J1. H.T. Rizal Nurdin Km. 4,5 Sihitang, Padangsidimpuan 22733 \\ e-mail: putrahsb.halomoan@gmail.com
}

\begin{abstract}
In Islamic marriage system, mahar is one of the prior concern although it is not any of rules (rukun) of the marriage itself. Etymologically, mahar means dowry. Terminologically, it refers to something which is given by a husband to bis wife as replacement or guarantee from him from what he takes from her. It can be either in form of things or sevices (such as setting slaves free, teaching, etc. Basically, mahar is genuinely the right of a wife. That means it is the wife that determines what and how many/much she wants it to be given to her. Even if she does not want anything for her mabar, a busband does not need to force to provide it. However, if his wife requires him to give her mahar, it should be whole and kind hearted gift to her. This reasonable since mahar symbolizes deep and true feeling of love and legal evidence of bond between a husband and a wife. However, in its implementation, mahar is not a simple as it may seem. Involving traditional and religious leaders in determining and approving mahar (as in Binabo Julu village) made few marriages postponed, unregistered (siri) or even cancelled. This also indicates that mahar potentially gives unexpected impacts toward the marriage it self
\end{abstract}

Kata kunci: mahar, pernikahan, dan hukum Islam

\section{PENDAHULUAN}

$M_{\text {Nomor } 1 \text { enurut }}^{\text {Undang-undang }}$ perkawinan adalah ikatan lahir batin antara seorang pria dengan wanita sebagai suami istri dengan tujuan membentuk keluarga (rumah tangga) yang bahagia dan kekal berdasarkan Ketuhanan yang Maha Esa.

Dalam Islam, perkawinan disebut sebagai transaksi ('aqad) yang mengandung unsur pengesahan hubungan suami istri antara seorang laki-laki dengan perempuan yang bukan mahramnya. Transaksi tersebut memuat unsur- unsur yuridis yang memberi legitimasi kepada seorang pria untuk menjaga, menuntun dan memelihara kesejahteraan wanita dan anakanaknya secara sah dan bertanggung jawab (Hamka, 2003: 213).

Perkawinan juga merupakan manifestasi kecintaan dan kasih sayang antara sesama manusia. Sebagaimana firman Allah SWT:

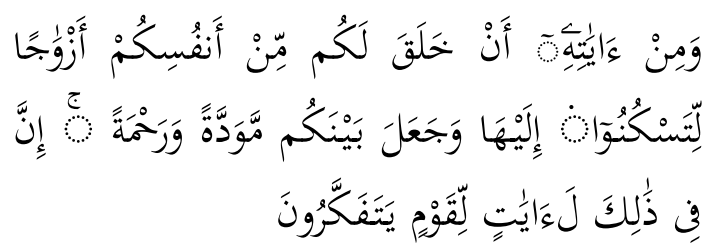

Dan diantara tanda-tanda kekuasaannya, Dia menciptakan untukmu istri-istri dari jenismu 
sendiri, supaya kamu cenderung dan merasa tentram kepada-Nya, dan dijadikan-Nya diantaramu rasa kasihsayang. Sesungguhnya pada yang demikian itu terdapat tandatanda bagi kaum yang berpikir. (Q.S. ar-Ruum [30]: 21) (Departemen Agama Republik Indonesia, t.th.: 25).

Dapat dipahami bahwa Allah SWT memberikan rahmat-Nya dengan perkawinan agar manusia dapat meneruskan keturunan dan menyalurkan kebutuhan biologisnya secara baik dan benar dalam rangka pengabdian diri kepada Allah SWT. Selain itu perkawinan juga bertujuan untuk memperoleh kedamaian, kebahagiaan, dan ikatan kekerabatan di antara suami istri. Islam menganjurkan bahwa apabila suatu perkawinan dianggap sah dilaksanakan oleh seseorang sesuai dengan ajaran agama Islam, yaitu dengan memenuhi unsur rukun dan syarat nikah (Nelli Jumni, 2008: 65).

Dalam pelaksanaan perkawinan Islam mahar merupakan prioritas utama sekalipun mahar tidak termasuk dalam kategori rukun nikah. Maskawin disebut juga dengan mahar, sadag, nihlah dan faridah. Menurut istilah syarak maskawin artinya suatu yang diberikan oleh laki-laki kepada istrinya sebagai tukaran atau jaminan bagi suatu apa yang diterima darinya (Dedi Rohayana, 2008: 35).

Maskawin atau mahar adalah merupakan hak calon istri, banyak sedikitnya maskawin atau mahar tersebut tergantung pada kehendak atau kemauaan calon istri itu sendiri, apabila dimaafkan saja oleh sang calon istri maka hilanglah kewajiban suami untuk memberikannya. Maskawin atau mahar tersebut boleh dimanfa'atkan oleh suami selama itu atas izin istri.

Di dalam buku yang lain dijelaskan "Seorang laki-laki harus memberikan mahar yang disukainya. Jika si istri berbaik hati dengan memberikan mahar atau memberikan sebahagiannya, setelah mahar itu disebutkan kuantitasnya, maka suami dapat memakannya sebagai makanan yang halal dan baik". Sebagaimana firman Allah SWT:

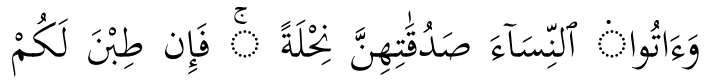

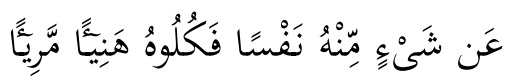

Dan berikanlah kepada perempuan itu maskawin mereka sebagai pemberian, maka apabila mereka berbaik hati kepadamu (rela hatinya) tentang suatu yang kamu berikan itu, makanlah olehmu harta itu secara senang hati pula. (Q.S. an-Nisa [4]: 4) (Departemen Agama Republik Indonesia, 1989: 46).

Adapun ketetapan dari Rasulullah tentang mahar ini adalah termaktub dalam kitab Shahih Bukhari dan Shohih Muslim yang artinya sebagai berikut :

Bahwa Nabi SAW melihat pada diri Abdurrahman bin Auf bekas warna kuning, lalu Nabi bertanya, apa ini? ia menjawab aku mengawini seorang wanita dengan maskawin satu biji Emas, lalu Nabi SAW bersabda mudah-mudahan Allah SWT memberikan keberkahan kepadamu. ini adalah ketetapan dari Nabi SAW. 
Hal ini adalah kesepakatan ulama umat Islam dan perilaku mereka dimana dan kapan saja.

Dari hadits Rasulullah di atas dapat kita ambil kesimpulan bahwa Rasulullah kurang menyukai mahar itu terlalu mahal (banyak).

\section{TINJAUAN MAHAR MENURUT ISLAM}

\section{Pengertian Mahar}

Mahar secara etimologi adalah Maskawin. Secara terminogi adalah pemberian wajib dari calon suami kepada istri sebagai ketulusan hati calon suami untuk menimbulkan rasa cinta kasih bagi seorang istri kepada calon suaminya. Atau suatu pemberian yang diwajibkan bagi calon suami kepada calon istri, baik berbentuk benda ataupun jasa (memerdekakan, mengajar, dan sebagainya).

Mahar hanya diberikan calon suami kepada calon istri, bukan kepada wanita lain atau siapapun, walaupun sangat dekat dengannya. Orang lain tidak akan boleh mengambilnya, bahkan suaminya sendiripun tidak boleh mengambilnya kecuali atas izin istrinya. Akan tetapi bila dibolehkan istrinya tidak ada halangan baginya untuk memakainya. Hal ini dijelaskan dalam al-Quran.

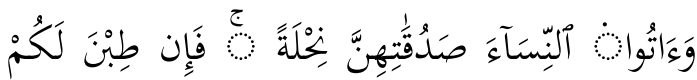

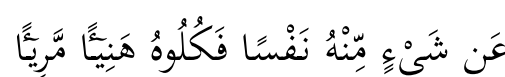

Dan berikanlah kepada perempuan itu maskawin mereka sebagai pemberian, maka apabila mereka berbaik hati kepadamu (rela hatinya) tentang suatu yang kamu berikan itu, makanlah olehmu harta itu secara senang hati pula. (Q.S. an-Nisa [4]: 4.) (Departemen Agama Republik Indonesia, 1989: 46).

Kata shadaq atau shaduqat yang dari rumpun kata shidiq, shadaq, bercabang juga dengan kata shadaqah yang terkenal. Di dalam maknanya terkandunglah perasaan jujur, putih hati. Jadi artinya adalah harta yang diberikan dengan putih hati, hati suci, muka jernih kepada calon istri yang akan dinikahi. Arti yang mendalam, mahar itu ialah laksana cap atau stempel, bahwa nikah itu telah dimateraikan.

Asal kata hikmah maskawin itu kita jumpai dalam alquran yang bersua dalam dua kata, pertama shaduqat yaitu pemberian dengan hati yang suci, kedua nihlah yaitu laksana madu yang disarikan lebah dari berbagai kembang, diserahkan kepada istri sebagai suatu kewajiban. Pemberian mahar ini adalah merupakan tanda kasih sayang dan menjadi bukti adanya ikatan antara seorang pria dengan wanita untuk membangun suatu rumah tangga (Abdurrahman, Abdullah, bin, al Bassam, 2006: 72).

Iman Syafi'i juga mengatakan bahwa mahar adalah sesuatu yang wajib diberikan seorang laki-laki kepada perempuan untuk dapat menguasai seluruh anggota badannya. Jika istri telah menerima maharnya, tanpa paksaan dan tipu muslihat, lalu ia meberikan maharnya, maka boleh diterima dan tidak disalahkan. Akan tetapi jika 
istri dalam memberikan maharnya karena malu atau takut maka tidak halal menerimanya. Hal ini sesuai dengan firman Allah SWT:

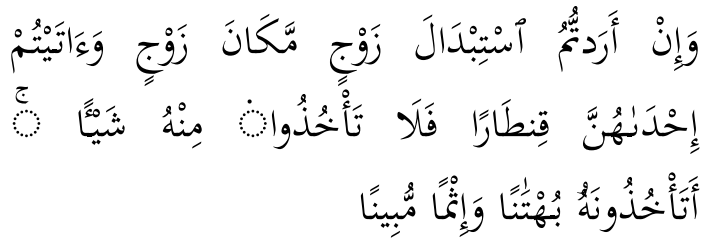

Dan jika kamu ingin mengganti istrimu dengan yang lain, sedangkan kamu telah memberikan kepada seseorang di antara mereka harta yang banyak, maka janganlah kamu mengambil kembali darinya barang sedikit pun. Apakah kamu akan mengambil dengan tuduhan yang dusta dan dengan ( menanggung) dosa yang nyata". (Q.S. an-Nisa [4]: 20)

\section{Dasar Hukum Mahar}

Syaikhul Islam Rahimahullahu berkata: "Termasuk Sunnah, meringankan maskawin dan mas kawin itu supaya tidak melebihi mas kawin istri-istri Nabi Shallahu 'alaihi wasallam dan putri-putrinya".

Dalam hadits lain Nabi Shallahu 'alaihi wasallam yang artinya

Maskawin yang paling baik adalah yang mudah.

Dalam hadits lain Nabi Shallahu 'alaihi wasallam bersabda yang artinya:

Padukanlah wanita-wanita itu pada para lelaki, dan janganlah berlebihan dalam maskawin.

Diriwayatkan dari Tirmizi dalam sebuah hadits shahih,

Ia berkata: Umar Ibn Khattab pernah berkhutbah di hadapan orang banyak yang isinya: Ketahuilah! Janganlah kamu berlebihan dalam memberikan maskawin kepada wanita-wanita, karena kalaupun maskawin itu adalah sebagai penghormatan di dunia atau sebagai ketaqwaan disisi Allah SWT, maka orang yang paling mulia di antara kamu adalah Nabi Shallahu 'alaihi wasallam, beliau tidak pernah memberikan maskawin kepada istriistrinya, dan di antara putri-putrinya tidak pernah diberi maskawin lebih dari dua belas Uqiyyah.

Dimakruhkan bagi laki-laki untuk memberi maskawin kepada istri-istrinya suatu maskawin yang pembayarannya menyusahkannya, atau sulit untuk dilunasi jika itu berupa pinjaman. Dalam pelaksanaan pembayaran mahar ini juga tidak bisa dipaksakan dengan kekerasan, maka ketika tidak mampu untuk membayar maka dilakukan perundingan.

Alquran menjelaskan tentang maskawin pada surah an-Nisa' $: 4$.

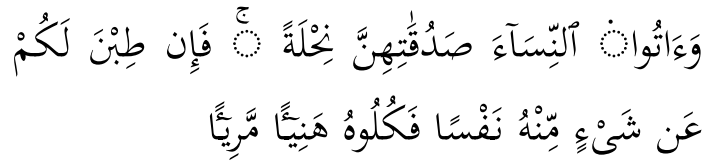

Dan berikanlah kepada perempuan itu maskawin mereka sebagai pemberian, maka apabila mereka berbaik hati kepadamu (rela hatinya) tentang suatu yang kamu berikan itu, makanlah olehmu harta itu secara senang hati pula . (Q.S. an-Nisa [4]: 4) (Departemen Agama Republik Indonesia, 1989: 46)

Ayat ini memberikan hak yang jelas kepada wanita dan hak keperdataan mengenai maskawinnya. Juga menginformasikan realitas yang terjadi dalam masyarakat jahiliyah, 
dimana hak itu dirampas dengan berbagai macam bentuknya. Misalnya pemegang hak maskawin itu di tangan wali dan ia berhak mengambilnya untuk dirinya, seakan-akan wanita itu objek jual beli sedangkan si wali sebagai pemiliknya.

Islam mewajibkan maskawin dan memastikannya, untuk dimiliki si wanita sebagai kewajiban dari lelaki kepadanya yang tidak boleh ditentang. Islam mewajibkan si suami memberikan maskawin sebagai "nihlah" (pemberian yang khusus kepada si wanita) dan harus dengan hati yang tulus dan lapang dada, sebagaimana memberikan hibah dan pemberian (Abd. Rahman Ghazaly, 2006: 45). Apabila kemudian si istri merelakan maskawinnya itu sebahagian atau seluruhnya kepada suaminya, maka si istri itu mempunyai hak penuh untuk melakukannya dengan senang hati dan rela hati, dan si suami boleh menerima dan memakan apa yang diberikan istri dengan senang hati. Karena hubungan antara suami istri seharusnya didasarkan pada kerelaan yang utuh, kebebasan yang mutlak, kelapangan dada, dan kasih sayang yang tidak terluka dari kedua belah pihak.

Dengan memperlakukan sistem seperti ini, Islam hendak menjauhkan sisa-sisa sistem jahiliyah mengenai wanita dan maskawinnya, hak-haknya terhadap dirinya dan harta bendanya, kehormatan dan kedudukannya. Diberikan keleluasaan, saling merelakan dan kasih sayang untuk mewarnai kehidupan bersama dan untuk menyegarkan

suasana

kehidupannya.

\section{Syarat Mahar}

Dalam Islam tentu sudah ada aturan main yang diatur oleh hukum Islam itu sendiri baik permasalahan ibadah, jinayah, siyasah, munakahat dan lain sebagainya.

Dalam fiqh munakahat telah disebutkan ada beberapa macam syarat sahnya mahar yang diberikan kepada calon istri, adapun syarat tersebut sebagai berikut: (Jaih Mubarok, 2002: 56)

1. Harta berharga. Tidak sah mahar dengan yang tidak berharga walaupun tidak ada ketentuan banyak atau sedikitnya mahar, mahar sedikit tapi bernilai tetap sah disebut mahar.

2. Barangnya suci dan bisa diambil manfaatnya. Tidak sah mahar dengan memberikan khamar, babi, atau darah, karena semua itu haram dan tidak berharga/suci.

3. Barangnya bukan barang ghasab. Ghasab artinya mengambil barang orang lain tanpa seizinnya namun tidak bermaksud untuk memilikinya karena berniat untuk mengembalikannya kelak. Memberikan mahar dengan barang ghasab tidak sah.

4. Bukan barang yang tidak jelas keadaannya. Tidak sah mahar dengan barang yang tidak jelas keadaannya, atau tidak disebutkan jenisnya.

\section{Macam-macam Mahar}

Adapun mahar itu terbagi kepada 2 macam yaitu : 


\section{Mahar musamma.}

mahar yang disepakati adalah pengantin laki-laki dan pengantin perempuan yang disebutkan dalam redaksi adat.

Dr. H. Abd. Rahman Ghazali, MA dalam bukunya mendefenisikan bahwa mahar musamma adalah mahar yang sudah disebut atau dijanjikan kadar dan besarnya ketika akad nikah (Abdurrahman, Abdullah, bin, al Bassam, 2006: 44).

Ulama Fiqh sepakat bahwa dalam pelaksanaannya, mahar musamma harus diberikan secara penuh apabila :

a. Telah bercampur (bersenggama)

b. Salah satu dari suami istri meninggal. Demikian ijma' ulama.

\section{Mahar mitsil (sepadan)}

Mahar mitsil adalah mahar yang tidak disebutkan besar kadarnya pada saat sebelum maupun ketika terjadi pernikahan, atau mahar yang diukur (sepadan) dengan mahar yang telah diterima oleh keluarga terdekat, dengan mengingat status sosial, kecantikan dan sebagainya.

Mahar mitsil ini terjadi dalam keadaan sebagai berikut: (Ibnu Taimiyah, Taqiyuddin, Imam al' Alamah, 1997: 58)

1. Apabila tidak disebutkan kadar mahar dan besarnya ketika berlangsung akad nikah, kemudian suami telah bercampur dengan istri, atau meninggal sebelum bercampur (bersenggama).

2. Jika mahar musamma belum dibayar sedangkan suami telah bercampur dengan istri ternyata nikahnya tidak sah.

Nikah yang tidak disebutkan dan tidak ditetapkan maharnya disebut nikah tafwidh. Hal ini menurut jumhur Ulama dibolehkan.

Firman Allah SWT dalam alquran:

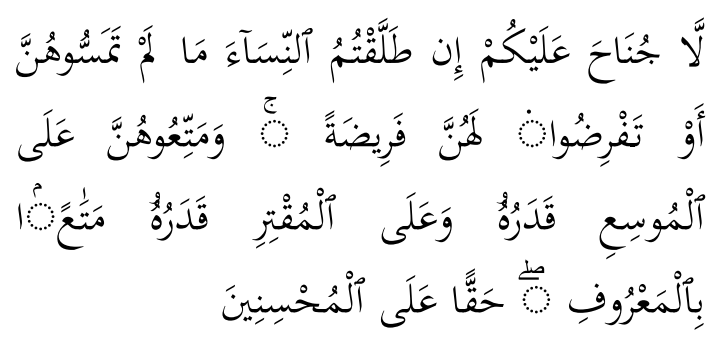

Tidak ada kewajiban membayar (mahar) atas kamu, jika kamu menceraikan istri-istri kamu sebelum kamu bercampur dengan mereka dan sebelum kamu menentukan maharnya. Dan hendaklah kamu berikan suatu mut'ah (pemberian) kepada mereka. Bagi yang mampu menurut kemampuannya dan bagi yang tidak mampu menurut kemampuannya (pula), yaitu pemberian dengan cara yang patut, yang merupakan ketentuan bagi orang-orang yang berbuat ihsan (Q.S. al-Baqarah [2]: 236).

\section{Ketentuan Mahar dalam Islam}

Mengenai kadar mahar ulama mazhab telah sepakat bahwa bagi mahar itu tidak ada batasan tertinggi. Ulama mazhab mengambil dalil firman Allah SWT:

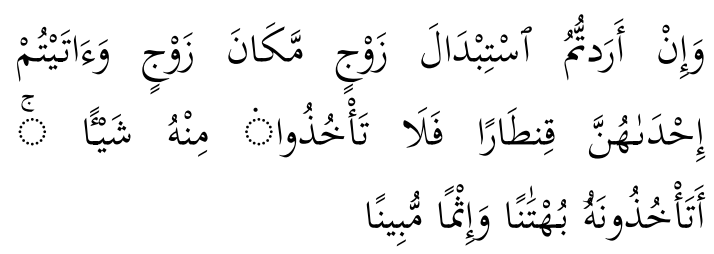


Dan jika kamu ingin mengganti istrimu dengan yang lain, sedangkan kamu telah memberikan kepada seseorang di antara mereka harta yang banyak, maka janganlah kamu mengambil kembali darinya barang sedikit pun. Apakah kamu akan mengambil dengan tuduhan yang dusta dan dengan (menanggung) dosa yang nyata (Q.S. an-Nisa' [4]: 20) .

Kemudian ulama mazhab berbeda pendapat dengan rendahnya mahar tersebut.

Syafi'i, Hambali, dan Imamiyah berpendapat bahwa tidak ada batas minimalnya. Mereka mengambil dalil Hadits Rasulullah SAW.

Kawinlah engkau walupun dengan maskawin cincin dari besi. (HR. alBukhari).

Hanafi berpendapat bahwa jumlah minimal mahar adalah sepuluh dirham. Kalau suatu akad yang dilakukan dengan mahar kurang dari itu, maka akad tetap sah, dan wajib membayar sepuluh dirham.

Maliki mengatakan jumlah minimal mahar adalah tiga dirham. Kalau akad dilakukan dengan mahar kurang dari hal tersebut, kemudian terjadi percampuran, maka suami harus membayar tiga dirham. Tetapi apabila belum bercampur maka suami boleh memilih antara membayar tiga dirham (dengan melanjutkan perkawinan) atau memfasakh akad, lalu membayar mahar musamma.

Adapun faktor penyebab perbedaan pendapat tentang kadar (ketentuan mahar) di kalangan ulama madzhab ada dua macam sebagaimana disebutkan oleh Ibn Rusyd, yaitu: (Sayyid Quthb, 2001: 34)

1. Ketidakjelasan akad nikah itu sendiri antara kedudukannya sebagai salah satu jenis pertukaran, karena yang dijadikan adalah kerelaan menerima ganti, baik sedikit maupun banyak, seperti halnya dalam jual beli dan kedudukannya sebagai ibadah yang sudah ada ketentuannya. Demikian itu kalau ditinjau dari segi bahwa dengan mahar itu lakilaki dapat memiliki jasa wanita itu selamanya, maka perkawinan itu mirip dengan pertukaran. Tetapi ditinjau dari segi adanya larangan mengadakan persetujuan untuk meniadakan mahar, maka mahar itu mirip dengan ibadah.

2. Adanya pertentangan antara qiyas yang menghendaki adanya pembatasan mahar dengan mafhum hadits yang tidak menghendaki adanya pembatasan. Qiyas yang menghendaki adanya pembatasan mahar adalah seperti pernikahan itu ibadah, sedangkan ibadah itu sudah ada ketentuannya.

\section{Penetapan Mahar dalam Islam}

Penetapan mahar adalah salah satu dari adat istiadat, dengan demikian hukum Islam mengatur hal tersebut dalam ' urf (adat istiadat ).

Kata 'urf secara etimologi adalah sesuatu yang dipandang baik dan diterima oleh akal sehat. Sedangkan secara terminologi, 
seperti dikemukakan oleh Abdul Karim Zaidan, istilah 'urf berarti :

Sesuatu yang tidak asing lagi bagi satu masyarakat karena telah menjadi kebiasaan dan menyatu dengan kehidupan mereka baik berupa perbuatan maupun perkataan.

'Urf baik berupa perbuatan maupun berupa perkataan, seperti dikemukakan Abdul Karim Zaidan, terbagi kepada dua macam (Farid Muhammad Washil, Nashr, Abdul Aziz Muhammad Azzam, 2009: 35).

1. al-'Urf al-'Am (adat kebiasaan umum), yaitu adat kebiasaan mayoritas dari berbagai negeri di suatu masa.

2. al-'Urf al-Khas (adat kebiasaan khusus), yaitu adat istiadat pada masyarakat atau negeri tertentu.

Di samping pembagian di atas, 'urf dibagi pula kepada dua macam.

1. Adat kebiasaan yang benar, yaitu suatu hal yang baik yang menjadi kebiasaan suatu masyarakat, namun tidak sampai menghalalkan yang haram dan tidak pula sebaliknya.

2. Adat kebiasaan yang fasid (tidak benar), yaitu suatu yang menjadi adat kebiasaan yang sampai menghalalkan yang diharamkan Allah.

Abdul Karim Zaidan menyebutkan beberapa persyaratan bagi 'urf yang bisa dijadikan landasan hukum yaitu:

1. 'Urf itu harus termasuk 'urf yang shahih, dalam arti tidak bertentangan dengan ajaran al quran dan Sunnah Rasulullah.

2. 'Urf itu harus bersifat umum, dalam arti minimal telah menjadi kebiasaan mayoritas penduduk negeri itu.

3. 'Urf itu harus sudah ada ketika sudah terjadinya suatu peristiwa yang akan dilandaskan kepada 'urf itu.

4. Tidak ada ketegasan dari pihakpihak terkait yang berlainan dengan kehendak' urf tersebut.

Allah SWT berfirman di dalam al Quran

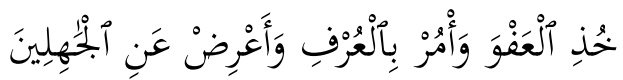

Jadilah engkau pema'af dan suruhlah orang untuk mengerjakan yang ma'ruf (al 'urf) serta berpalinglah dari orang-orang yang bodoh. (Q.S. al-A'raf [7] : 199.)

Hadits Rasulullah SAW (Hadits tentang mahar, www. http//hadist tentang mahar//, diakses pada 12 Nopember 2015 ).

1. Dalam satu riwayat Rasulullah SAW bersabda yang artinya: Apa yang dipandang baik oleh umat Islam, baik pula di sisi Allah SWT.

2. Diriwayatkan oleh al Hakim. Tidak boleh menyulitkan orang lain dan tidak pula dipersulit orang lain. Orang yang mempersulit orang lain akan dipersulit oleh Allah dan orang yang memusuhi orang lain akan dimusuhi oleh Allah.

Dalam hal ini ulama fiqh juga mengatakan sbb :

1. Adat kebiasaan dapat ditetapkan sebagai hukum".

2. Menentukan dengan dasar 'urf seperti menentukan dengan berdasarkan nash".

3. Diambil mudharat yang lebih ringan di antara dua mudharat". 


\section{Pendapat Ulama tentang Mahar}

\section{Macam-macam Mahar}

Ulama Madzhab (Ja'fari, Hanafi, Maliki, Syafi'I, dan Hambali) sepakat mengatakan bahwa mahar hanya dibagi kepada dua macam yaitu mahar musamma dan mahar mitsil (Hajar, Ibnu, al' Asqolani, t.th.: 35).

1. Mahar musamma

Mahar musamma adalah mahar yang disepakati oleh pengantin laki-laki dan perempuan yang disebutkan dalam redaksi adat.

2. Mahar mitsil (sepadan).

Mahar mitsil adalah mahar yang tidak disebutkan besar kadarnya pada saat sebelum maupun ketika terjadi pernikahan.

\section{Syarat Mahar}

Seluruh ulama mazhab sepakat bahwa mahar boleh berupa uang, perhiasan, perabot rumah tangga, harta perdagangan, atau bendabenda lain yang mempunyai harga. Menurut seluruh mazhab kecuali Malikiyah disyaratkan bahwa mahar harus diketahui secara jelas dan ril atau secara global mengenai jumlahnya, maka apabila tidak, maka akad tetap sah tetapi mahar batal. Sedangkan menurut Malikiyah berpendapat akadnya fasid (tidak sah) dan difaskh sebelum terjadi percampuran, tetapi bila terjadi percampuran maka akad dinyatakan sah dengan menggunakan mahar mitsil.

Mengenai mahar musamma yang diberikan berupa barang haram maka Maliki mengatakan apabila belum terjadi percampuran akadnya fasid, tetapi bila telah terjadi percampuran maka akad dinyatakan sah dan si istri berhak atas mahar mitsil. Sedangkan ulama yang lain mengatakan akad tetap sah dan si istri berhak atas mahar mitsil.

Mengenai mahar musamma berupa harta rampasan, ulama Malikiyah berpendapat bahwa kalau perabot itu adalah barang yang dikenal keduanya maka akad dinyatakan fasid dan difashk sebelum tejadi percampuran. Tetapi apabila sudah terjadi percampuran akad dinyatakan sah dengan menggunakan mahar mitsil. Ulama Syafi'iyah dan Hambaliyah menyatakan bahwa akad tetap sah dan si istri berhak atas mahar mitsil. Sedangkan Ulama Imamiyah dan Hanafiyah mengatakan akad tetap sah, akan halnya mahar, apabila diberikan pada saat itu maka itulah yang menjadi mahar musammanya (maharnya sah), maka apabila tidak diberikan pada saat itu maka si istri berhak memperoleh pengganti berupa barang yang sama.

\section{Tinjauan Hukum Islam terhadap Penetapan Mahar}

Penetapan mahar merupakan pelaksanaan adat pada masyarakat. Penetapan mahar tersebut di laksanakan melalui musyawarah secara khusus di rumah calon istri yang di hadiri oleh pihak calon istri dan calon suami yang dianggap penting, penetapan Mahar adalah bahagian dari 'urf (adat kebiasaan) yang berkembang dan dilestarikan 
masyarakat yang bersangkutan. Menurut hemat penulis penetapan mahar yang dilakukan merupakan bahagian dari 'urfun shohih yaitu suatu hal yang baik yang menjadi kebiasaan masyarakat, namun tidak sampai menghalalkan yang haram dan tidak pula sebaliknya. Dalam hal 'urfun shohih Allah SWT memerintahkan untuk selalu dilaksanakan. Sebagaimana firmanNya di dalam al Quran surah al A'raf : 199.

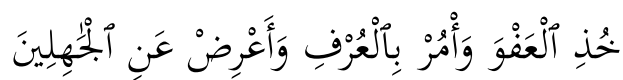

Jadilah engkau pema'af dan suruhlah orang untuk mengerjakan yang ma'ruf ( al 'urf) serta berpalinglah dari orang-orang yang bodoh. (Q.S. al-A'raf [7]: 199)

Dari penelitian yang penulis lakukan, penulis melihat bahwa penetapan mahar di Desa Binabo Julu mempunyai dampak yang signifikan terhadap kelangsungan pernikahan, seperti : Tertundanya pelaksanaan akad nikah, terjadinya nikah sirri, Adanya rencana pernikahan yang dibatalkan, Walimatul 'usry yang hanya dilaksanakan oleh satu pihak, dan Melonggarnya nikah sesama suku. Namun, penulis melihat, bahwa penyebab dari semua hal tersebut karena besarnya kadar mahar yang diminta oleh pihak calon istri itu sendiri. Dalam hal besarnya kadar mahar tidak ada larangan dalam alquran maupun sunnah Rasulullah SAW, namun Rasulullah menganjurkan kepada umatnya untuk memudahkan maskawin. Sebagaimana dijelaskan dalam Haditsnya yang berbunyi sebagai yang artinya "maskawin yang paling baik itu adalah yang mudah".

Penulis melihat bahwa dalam penetapan mahar tersebut terdapat dua kumudharatan yaitu, Pertama dengan tingginya kadar mahar yang diminta pihak calon istri dalam penetapan mahar maka kebanyakan dari pihak laki-kaki merasa keberatan dengan ketentuan tersebut. Kedua bila kadar mahar itu rendah maka dikhawatirkan akan merajalelanya perceraian. Dalam kasus seperti ini ulama fiqh menjelaskan bahwa apabila ada satu perbuatan yang mempunyai dua mudharat maka boleh dikerjakan yang lebih sedikit mudharatnya. Dengan qaidah sebagai berikut : "Diambil mudharat yang lebih ringan diantara dua mudharat".

\section{PENUTUP}

\section{Kesimpulan}

1. Penetapan mahar merupakan pelaksanaan adat Dalihan $\mathrm{Na}$ Tolu, di laksanakan dengan musyawarah kedua belah pihak. Dilaksanakan secara khusus di rumah pihak perempuan dengan mengumpulkan famili dari pihak laki-laki dan perempuan. Dalam penetapan mahar selalu menggunakan bahasa adat.

2. Tata cara penetapan mahar merupakan persetujuan dari tokoh adat dan tokoh agama. Ketetapan mahar yang di tetapkan terdapat dampak negatif yang sangat signifikan terhadap kelangsungan pernikahan, yaitu :

a. Tertundanya pelaksanaan akad nikah. 
b. Terjadinya nikah lari (nikah sirri).

c. Adanya pernikahan yang di batalkan

d. Walimatul 'ursy hanya dilaksanakan satu pihak.

e. Melonggarnya nikah sesama suku.

3. Penetapan mahar yang keputusan didominasi pihak perempuan, banyak dari pihak laki-laki yang merasa keberatan dengan hal tersebut, karena menyebabkan, bahkan mempengaruhi mahalnya kadar mahar yang diminta pihak perempuan dalam prosesi penetapannya.

4. Penetapan mahar yang mahal dilakukan bertujuan untuk menghindari terjadinya perceraian, terciptanya rasa tanggung jawab suami terhadap istrinya, tanggung jawab orang tua terhadap anak-anaknya dan terjadinya sifat terhormat kedua belah pihak. Dengan demikian, penetapan mahar sesuai dengan hukum Islam.

\section{Saran}

Setelah melihat, mengamati dan mencermati penetapan mahar, penulis dengan berbesar hati memberikan saran sebagai berikut:

1. Kepada tokoh adat kiranya untuk lebih melihat kepada konteks agama dalam pengaturan pernikahan khususnya penetapan mahar.

2. Kepada tokoh agama agar mendahulukan nash dalam mengambil keputusan (membuat aturan) dibanding adat istiadat, supaya nikah sirri tidak terjadi.

3. Kepada orang tua calon istri agar lebih melihat kepada kebahagiaan anak dan keadaan ekonomi pihak calon suami.

4. Kepada pemuda jangan boros, mulailah berpikir untuk masa depanmu, jangan sampai menyusahkan kepada orang tua.

5. Kepada pemudi pelajari syari'at. Jangan sampai hakmu di rampas oleh orang lain.

\section{DAFTAR KEPUSTAKAAN}

Abdul Karim Amrullah, Abdul Malik., 2003. ( HAMKA ),Tafsil Al-azhar Jilid 2, Singapura : Pustaka Nasional PTE LTD, Cet. Ke-5.

Agama Republik Indonesia, Departemen. t.t. Al Qur an dan Tafsirnya Jilid II, Semarang : Effhar Offset.

1989. al-Qur'an dan Terjemahnya, Semarang : CV Toha Putra, ,Cet. ke-4

Abdurrahman, Abdullah, bin, al Bassam, 2006. Syarah Bulughul Marom, Jakarta : Pustaka Azzam, Cet. ke-1, jilid 5.

Bakry, Hasbullah, 1985. Kumpulan Lengkap Undang-Undang dan Peraturan Perkawinan di Indonesia, Jakarta : Djambatan, Cet. ke-3.

Dalimunte, Marwan,Adat Dalihan Natolu, di unduh dari http:// sirajasonang. wordpress.com. 
Dedi Rohayana, Ade, 2008. Ilmu Qowa'id Fighiyyah Kaidah-kaidah Hukum Islam, Jakarta : Gaya Media Pratama, cet. Ke-1.

Farid Muhammad Washil, Nashr, Abdul Aziz Muhammad Azzam, 2009. Qowa'id Fiqhiyyah, Jakarta : Amzah, Cet. Ke-2.

Ghazaly, Abd. Rahman, 2006. Figh Munakahat, Jakarta: Kencana, ed. 1 , cet. Ke-1

Hajar, Ibnu, al'Asqolani, tt’ Bulughul Marom min adallatil Ahkam, Jeddah : Alharomaini Liththoba'ati Wannasyri Wattauzi'i.

Ibnu Taimiyah, Taqiyuddin, Imam al' Alamah, Penerjemah Rusnan Yahya, 1997. Hukumhukum Perkawinan, Jakarta : Pustaka Al-Kautsar, Cet. Ke-1

Jawad Mughniyah, Muhammad, 2001. Fiqih Lima Mazhab, Jakarta : PT. Lentara.

Mas'ud, Ibnu, 2000. Fiqih Madzhab Syafi'i, Bandung : CV. Pustaka Setia, Cet. ke-1, jilid 2.
Mubarok, Jaih, 2002. Kaidah Figh Sejarah dan Kaidah Asasi, Jakarta : Raja Grafindi Persada, ed. 1, Cet. Ke-1.

Mu'in, A, dkk, 1986. Ushul Figh Qaidah-qaidah Istinbath dan Ijtihad ( Jakarta : Dirjen. Pembinaan Kelembagaan Agama Islam Departemen Agama.

Nasib ar-Rifa'i, 1999. Muhammad, Ringkasan Tafsir Ibnu Katsir, Jakarta : Gema Insani, Cet ke-1, Jilid 1.

Nelli Jumni, M. Ag, 2008. Figh Munakahat, Pekanbaru : Suska Press.

Sayyid Quthb, Syahid, Penerjemah : As'ad Yasin, Abdul Aziz Salim Basyarahil dan Muchotob Hasan, 2001. Tafsir Fi Zhilalil Qur an,( Jakarta : Gema Insani Press, Cet.Ke- 1 